\title{
Sharing our Planet with Wildlife
}

\author{
Sidney Holt
}

Man's efforts to manage marine resources have so far proved conspicuously unsuccessful. The prime cause is human greed, which we rationalise as a scientific concept and call achieving 'maximum sustainable yield', in the arrogant belief that we know how to achieve it. But, says the author, we do not know; we do not even know how to manage ourselves. He believes that one path man should explore is the scientific study of communication between individuals of a species - he suggests dolphins or whales - as a pointer to the possibility of communication between animals and humans. Such studies might, he thinks, help humans to shed their present arrogance and save us from the consequences of our destructive behaviour.

So far all efforts to achieve a condition of sustainable use of living marine resources have, by and large, been unsuccessful. In recent years nature has given us some sharp warnings: two successive collapses of the huge anchovy fishery off Peru and Chile; the collapse of herring stocks in the North Sea; and the recent collapse of capelin stocks in the north-west Atlantic. The last example is interesting. The capelin is a small smelt-like fish, food of the whales, cod and other fishes in the north Atlantic. Humans have been catching capelin for a decade, in enormous quantities, to make fishmeal to feed to hens and pigs. We are not sure what effect its depletion has had on the cod and the seals - although there are ominous signs this year - but the effect on the humpback whales is a completely unpredicted one. On the Newfoundland coast these animals seem to have taken to coming closer inshore, looking for alternative food, and in doing so they become entangled with fishing nets and have caused millions of dollars worth of damage.

All these events have occurred, not because these fisheries were not managed, but in spite of the fact that catch quotas calculated on a supposedly scientific basis were set for them; and by and large, these quotas have been honoured. Natural climate variations played their part in these disasters, but the prime fault is in human greed. We have rationalised this greed as a 'policy' of taking the so-called maximum sustainable yield from wild populations of animals - in these cases from formerly abundant marine fishes. I call this policy one of brinkmanship. We try to reach the peak of a mountain and to cling to that peak. But any mountaineer would tell us that, with inadequate maps, poor equipment, swirling clouds around us and variable winds blowing, this is a formula for disaster.

At this point, I must confess to a feeling of guilt. For I know that I have played my part in encouraging the arrogant belief that we now know how to move profitably but safely over this wild terrain - that is how to calculate where we are and how to regulate ourselves so as to reach and keep a firm hold on some optimum state, which, incidentally, we have defined in our own terms. But we do not know how. Such godlike power is not in our reach, and probably never will be.

Despite these and other failures there is still much chatter in the world about managing living resources on scientific principles. This idea is embedded in 
national legislation and in international agreements. It is re-affirmed in the new drafts of the law of the sea. I think we scientists who juggle with mathematical models of biological systems have played a confidence trick on the world, and no-one has been more taken in by this trick than the fisheries administrators. They in turn have been busily playing the same trick on diplomats, lawyers, and the public at large. We did not start out dishonest, but we did begin to believe our own patter - and that is dangerous.

Now, the essence of a good confidence trick is that the accompanying patter is 99 per cent true; the con is in the one per cent. It is true that fishery resources are limited, not infinite, and to a degree renewable. It is true that we can learn something about their behaviour by analysis - by putting tags on fishes, by reading the ages of fishes from their scales, and of whales from their teeth and the wax in their ears, by collecting statistics of deaths, and so on. I do not want to be labelled as a renegade turned against science, for I believe that our attempt through science to understand the natural world, especially the living world and our place in it, is the supreme contribution of our species to continued evolution of life on this planet. But I do hope for more humility in this attempt. And specifically, at this moment, I wish we could put more effort into appraising the practical consequences of our continued ignorance and resulting uncertainty - and try to act accordingly, for our own good.

The challenge is to manage ourselves rather than claim, ever more stridently, that we can, should and will manage the living world. We have the illusion, just because we have learned to count and manipulate, that we have escaped from the feedback mechanisms which regulate populations of other animals - not only the numbers of those animals but their collective behaviour. We have not escaped, we have merely delayed the action of those control mechanisms, created diversions. We now need to discover - or invent - new feed-back mechanisms, again not solely to regulate our numbers, but also our destructive behaviour. There are on offer several prototype models for such mechanisms. I will mention one of them, and it is connected with my efforts with many other persistent, courageous and clever spirits - to bring a little order into whaling.

The mechanism I have in mind is a kind of window. Professor Griffin, of Rockefeller University, wrote a few years back about 'a window on the minds of animals'. He was referring to the scientific study of communication between individuals of a species as a way to opening communication between that species and humans. With a few other fools wandering where angels fear to tread, I have come to the conclusion that we have a possibility of achieving this communication with some dolphins, and perhaps with whales, in the near future. There have very recently been important results in demonstrating 'intelligence' in dolphins - intelligence by our definition, that is. There is much circumstantial evidence for such intelligence to a high degree in larger species, such as the killer whale and the sperm whale. Dr Bergin, an eminent Russian expert on sperm whales, said in 1972, the year of the Stockholm Conference:

'(The sperm whale) is undoubtedly an animal with a cortex of complex structure corresponding to complex psychic manifestations. The sperm whale brain must possess an extreme functional plasticity and practically inexhaustible possibilities for establishing links between stimuli and the form of reactions. The sperm whale brain is such that its possessor can be said to be a "thinking" animal capable of displaying high "intellectual abilities".' 
The next year the American astronomer, Carl Sagan, wrote:

'Though the search for extraterrestial intelligence may taken a very long time, we could not do better than to start a program of rehumanization by making friends with whales and dolphins'.

By contrast, the Panamanian delegate to the International Whaling Commission pointed out in 1978 that in modern whaling all parts of the sperm whale are utilised, with one exception-the brain. For that industrial man can find no use!

Now here we have a dilemma. Some of my friends have said to me: 'We must not argue to save whales because they are "intelligent" - or might be. That is élitist, and will have bad repercussions on efforts to save other species'. I have thought a lot about that, and I made a personal decision to use the argument of intelligence. This for two reasons. Firstly a pragmatic reason: the cards are so stacked against conservation we need to use every argument we can find, in every case; second, and more important: if we can gain insight to the minds of whales and dolphins we may not only learn to treat them politely, and with deeper respect, but may begin to shed the arrogant humanism which, while recognising our bodily continuity in evolution with other animals, still insists on a mental discontinuity between 'us' and 'them'. If we do gain such insight we shall at last understand our mental continuity with fishes and turtles, and save them from our excesses, and eventually save us from ourselves. This is no longer the view of just a few aberrant individuals. In 1977 the Federation of American Scientists, an eminently respectable body, agreed that:

'In the twentieth century man has generally accepted his evolutionary descent from lower animals. But he has not yet accepted an obvious corollary to Darwinian evolution. A spectrum of emotional and of intellectual ability among the animals. This blindness must eventually fall.'

We have taken a few steps towards ending the totally unnecessary slaughter of whales. To this modest success many factors have contributed, not least the historic symbolic role of these creatures, enhanced in recent years by their great beauty as revealed in underwater photography and sound recording. At the same time we begin to threaten the whales in a new way - by undermining their food supplies, especially the krill in the Antarctic. I am immensely glad that IUCN and WWF have taken the lead - where bigger organisations have feared to go because of the pressures from a few jealous governments - by encouraging, in a concrete way, the study of the dynamics of the Southern Ocean from the point of view of urgent conservation needs.

The WWF proclaimed in San Francisco in 1976 that 'The Seas Must Live', and made the humpback whale the explicit symbol of that intent. I would now like to extend that idea from an imperative directed, apparently, to no-one in particular, to a plea directed to all of us. This was voiced by my friend Phoebe Wray, of the Center for Action on Endangered Species, at a recent gathering in New England to talk about whales. She said, quietly, 'Save the whales, save the ocean, share the planet.' And I leave you with the words of Hazel Henderson, another sensitive woman of our time: 'We have not inherited the planet from our parents. We have borrowed it from the children.'

In November 1979 Professor Holt, who is chairman of the SSC Marine Mammal Specialist Group, received the WWF Gold Medal for outstanding services to marine conservation. This article is part of his speech of thanks to the WWF Board of Trustees. 